\title{
Brain Based Learning dalam Pembelajaran Bahasa Jerman
}

\author{
${ }^{1}$ Fikayatuz Zakiyah, ${ }^{2}$ Rosyidah
}

\author{
Universitas Negeri Malang, Malang, Indonesia
}

Email: ${ }^{1}$ fikayatuz.zakiyah.1602416@ students.um.ac.id, ${ }^{2}$ rosyidah.fs@um.ac.id

\begin{tabular}{l}
\hline Tersedia Online di \\
\hline http://www.jurnal.unublitar.ac.id/i \\
ndex.php/briliant
\end{tabular}

\section{Sejarah Artikel}

Diterima pada 19 October 2020

Disetujui pada 16 February 2021

Dipublikasikan pada 28 Februari 2021

Hal. 50-65

\section{Kata Kunci:}

Brain Based Learning; Bahasa

Jerman; pembelajaran; model pembelajaran

\begin{tabular}{l}
\hline DOI: \\
\hline http://dx.doi.org/10.28926/briliant. \\
v3i4.572
\end{tabular}

\begin{abstract}
Abstrak: Artikel ini membahas model pembelajaran Brain Based Learning secara konseptual dan contoh implementasinya dalam pratik pembelajaran bahasa Jerman di SMA. Metode yang digunakan dalam penelitian ini adalah metode penelitian kepustakaan yang mempelajari dan mengumpulkan data dari referensi yang relevan dengan topik pembahasan. Hasilnya menunjukkan bahwa penerapan model pembelajaran Brain Based Learning dapat menjadi solusi untuk mengatasi problematika dalam pembelajaran bahasa Jerman. Konsep dasar dari model pembelajaran Brain Based Learning adalah pembelajaran dilakukan dengan menyelaraskan sistem kerja otak yang didesain secara alamiah untuk belajar. Melalui penerapan model pembelajaran ini, guru dapat mengasah seluruh potensi yang dimiliki siswa sehingga pembelajaran berlangsung secara optimal. Pelaksanaan penerapan model pembelajaran Brain Based Learning terdiri atas 7 tahap, yaitu (1) tahap prapemaparan, (2) tahap persiapan, (3) tahap inisiasi
\end{abstract}

dan akuisisi, (4) tahap elaborasi, (5) tahap inkubasi dan internalisasi, (6) tahap verifikasi dan konfirmasi, serta (7) tahap selebrasi dan integrasi.

\section{PENDAHULUAN}

Saat ini, dunia pendidikan Indonesia mendapat sorotan tajam terkait efektivitas model pembelajaran bahasa asing yang diterapkan di sekolah. Latar belakang munculnya kritikan tersebut adalah rendahnya kualitas output siswa dalam penguasaan bahasa Inggris sebagai bahasa asing utama yang dipelajari di sekolah (Efendi, 2013). Berdasarkan survei yang diadakan oleh EF English Proficiency Index for Schools (EF EPI-s) pada tahun 2019 terkait keterampilan bahasa Inggris siswa di seluruh dunia, Indonesia menempati posisi 61 dari 100 negara dengan skor akhir 50,06. Hasil penelitian tersebut membuktikan bahwa pembelajaran bahasa asing di Indonesia memiliki kualitas yang tergolong rendah. Banyak siswa lulusan SMA tidak mampu menggunakan bahasa Inggris dalam konteks komunikasi sehari-hari (Yusuf, 2017). Situasi ini juga tidak jauh berbeda dengan hasil pembelajaran bahasa Jerman di Indonesia.

Pelaksanaan pembelajaran bahasa Jerman sebagai bahasa asing di SMA mengalami berbagai kendala, sehingga banyak lulusan dinilai belum berhasil mencapai standar kompetensi pembelajaran bahasa Jerman yang diharapkan. Berdasarkan penulusuran hasil penelitian di berbagai jurnal online terkait 
pelaksanaan pembelajaran bahasa Jerman, peneliti menyimpulkan bahwa terdapat tiga faktor utama penyebab terjadinya kendala dalam pembelajaran bahasa Jerman di sekolah, yaitu (1) motivasi siswa dalam mempelajari bahasa Jerman rendah, (2) model pembelajaran lebih menekankan penguasaan teoretis daripada praktis, dan (3) pelaksanaan pembelajaran masih didominasi oleh guru.

Menurut Haeniah (2019), pelaksanaan pembelajaran merupakan representasi dari komponen pembelajaran yang berorientasi pada kebermaknaan belajar bagi siswa. Oleh karena itu, untuk mengatasi permasalahan-permasalahan di atas diperlukan penerapan model pembelajaran yang bermakna dan mampu menciptakan situasi pembelajaran yang menyenangkan bagi siswa. Model pembelajaran yang menyenangkan akan menciptakan situasi belajar mengajar menjadi nyaman, sehingga siswa lebih bersemangat untuk terlibat aktif dalam setiap proses pembelajaran di kelas. Selain itu, penggunaan/perancangan model pembelajaran yang tepat akan membantu keberhasilan dalam pemahaman materi pelajaran yang akan disampaikan (Wirajayadi, 2016).

Untuk mewujudkan situasi tersebut, guru perlu memahami cara kerja otak sebagai pusat sistem kecerdasan manusia. Sehubungan dengan hal tersebut, Handayani dan Corebima (2017) berpendapat bahwa guru akan lebih mudah mendesain model pembelajaran, apabila telah memiliki pemahaman terkait sistem kerja otak siswa. Salah satu model pembelajaran yang dapat mengakomodasi sistem/cara kerja otak adalah model pembelajaran berbasis otak yang biasa dikenal dengan istilah Brain Based Learning ( $B B L)$.

Model pembelajaran $B B L$ menawarkan konsep desain pembelajaran yang menyelaraskan sistem kerja otak secara alamiah untuk belajar (Jansen, 2011). Senada dengan pendapat tersebut, Yusuf (2017) menegaskan bahwa pembelajaran dengan menyelaraskan prinsip dasar kerja otak tidak hanya mengasah kemampuan kognitif siswa, tetapi dapat juga mengembangkan kreatifitas, rasa percaya diri, kemampuan berinteraksi kelompok, dan memotivasi siswa untuk belajar secara alamiah. Selain itu, model pembelajaran $B B L$ merupakan suatu model pembelajaran yang menjadikan siswa aktif membangun pengetahuan secara mandiri dengan memanfaatkan dan memberdayakan kemampuan otak yang dimiliki (Widyantara, Ganing, \& Zulaikha, 2015).

Model pembelajaran $B B L$ menawarkan konsep desain pembelajaran yang menyelaraskan sistem kerja otak secara alamiah untuk belajar (Jansen, 2011). Dalam hal ini, Lymbic system atau otak tengah memiliki peran penting dalam proses pembelajaran karena berfungsi untuk menyimpan ingatan dari pengalaman nyata, dan juga terlibat dalam penciptaan emosi (Buzan, 2009; Yusuf, 2017). Penerapan model pembelajaran $B B L$ mendukung guru agar mampu memunculkan emosi postif pada siswa sehingga mereka dapat belajar secara alamiah tanpa ada unsur keterpaksaan. Munculnya emosi positif tersebut dapat merangsang otak untuk menghasilkan braintransmitter (Neurotransmitter) yang disebut dengan dopamin (Ardiyani \& Yulianto, 2017). Dopamin merupakan hormon dalam tubuh yang bertugas untuk menyampaikan pesan pada sel saraf ketika seseorang sedang merasa bahagia (Putra, 2019). Apabila siswa belajar dengan perasaan bahagia dan tidak melalui paksaan, maka mereka dapat konsentrasi dan mengingat materi pembelajaran dalam jangka waktu yang lebih lama. Oleh karena itu, model 
pembelajaran $B B L$ cocok untuk diterapkan pada pembelajaran bahasa, terutama bahasa asing yang membutuhkan memori yang kuat untuk mengingat daftar kosa kata baru.

Berdasarkan paparan di atas, penerapan model pembelajaran $B B L$ kiranya dapat dijadikan sebagai salah satu alternatif untuk mengatasi problematika dalam pembelajaran bahasa Jerman sebagai bahasa asing di sekolah. Sesuai dengan konsep dasarnya, model pembelajaran ini diharapkan mampu memfasilitasi kinerja otak siswa, sehingga mereka dapat belajar secara alamiah tanpa ada unsur keterpaksaan. Lebih jauh lagi, melalui model pembelajaran tersebut diharapkan dapat dihasilkan output yang sesuai dengan tujuan dan standar kompetensi pembelajaran bahasa Jerman yang telah ditetapkan.

Dalam artikel ini, dibahas secara mendalam konsep-konsep penting terkait model pembelajaran $B B L$ melalui pengkajian dan penyajian dari berbagai teori yang relevan, serta contoh implementasinya pada praktik pembelajaran bahasa Jerman sebagai bahasa asing di SMA.

\section{PEMBAHASAN}

\section{Pembelajaran Bahasa Jerman sebagai Bahasa Asing}

Pembelajaran bahasa asing didefinisikan sebagai proses mempelajari bahasa dari suatu wilayah atau negara, tetapi bahasa tersebut hanya diajarkan di sekolah dan tidak digunakan sebagai alat komunikasi sehari-hari (Ghazali, 2000; Suryaningrum, 2016). Ruang lingkup pembelajaran bahasa asing di sekolah terdiri dari tiga aspek, yaitu (1) keterampilan berbahasa (menyimak, berbicara, membaca, dan menulis), (2) sub-kompetensi yang meliputi tindak bahasa, linguistik, sosiokultural, strategi dan kompetensi wacana, serta (3) pengembangan sikap positif terhadap bahasa asing sebagai alat komunikasi (Khosiyono, 2018; Kusumah, 2007).

Salah satu bahasa asing yang dipelajari siswa Indonesia di sekolah, terutama di tingkat Sekolah Menengah Atas (SMA) adalah bahasa Jerman. Pembelajaran bahasa Jerman di SMA memiliki empat keterampilan dasar berbahasa yang harus dikuasai oleh siswa, yaitu menyimak (Hören), berbicara (Sprechen), membaca (Lesen), dan menulis (Schreiben). Dalam Silabus Mata Pelajaran Bahasa dan Sastra Jerman Tingkat SMA/MA yang diterbitkan oleh Depdiknas (Edisi revisi tahun 2016), disebutkan bahwa tujuan pembelajaran bahasa Jerman sebagai bahasa asing di sekolah adalah siswa mampu menggunakan beragam fungsi sosial kebahasaan untuk berkomunikasi, baik lisan atau tulis dalam berbagai situasi dan topik dengan menggunakan Bahasa dan Sastra Jerman yang sederhana setara level A1.

Secara umum, istilah Deutsh als Fremdsprache (DaF) atau dalam bahasa Indonesia dikenal dengan istilah pembelajaran bahasa Jerman sebagai bahasa asing, dapat dipahami sebagai pengajaran bahasa untuk penutur asing (Ausländer), dan juga mencakup bidang penelitian terkait pelaksanaan $D a F$, baik di sekolah maupun universtias (Niekra, 2016). Lebih lanjut, Gotze \& Pommerin (dalam Septami, 2015) mengemukakan bahwa pembelajaran bahasa Jerman sebagai bahasa asing merupakan mata pelajaran yang diajarkan di suatu institut, baik di dalam maupun di luar negara Jerman yang dapat digolongkan sebagai pembelajaran bahasa secara umum maupun khusus. Dalam pelaksanaannya, DaF 
mengacu pada semua kegiatan pembelajaran praktis dan akademik yang berhubungan dengan bahasa dan budaya Jerman (Barkowski \& Krumm, 2010).

Berdasarkan uraian di atas, dapat disimpulkan bahwa pembelajaran bahasa Jerman sebagai bahasa asing di sekolah merupakan aktifitas pembelajaran yang bertujuan agar siswa mampu berkomunikasi baik secara lisan atau tulis, sesuai dengan tingkatan dan standar kompetensi pembelajaran bahasa Jerman. Selain sebagai alat pengembangan siswa dalam bidang komonikasi, pembelajaran bahasa Jerman sebagai bahasa asing juga berfungsi sebagai pengembang ilmu pengetahuan, teknologi, serta budaya.

\section{Model Pembelajaran $B B L$}

Sebelum membahas tentang pengertian model pembelajaran $B B L$, ada baiknya kita mengetahui sejarah munculnya model pembelajaran tersebut. Model pembelajaran ini awalnya berkembang dari konsep The Triune Brain Theory yang dikemukakan oleh Paul MacClean pada tahun 1970 (Hermann, 1994; Nikmah, 2015). McClean berhipotesis bahwa otak manusia pada dasarnya terdiri dari tiga bagian penting, yaitu (1) cerebrum (otak besar), (2) reptilian brain (otak reptil), dan (3) limbic system (sistem limbik/otak mamalia/otak tengah). Ketiga bagian tersebut memiliki fungsi masing-masing, yaitu:

a. Cerebrum atau otak besar yang memiliki fungsi utama untuk mengelolah bahasa, berbicara, mengendalikan cara berpikir, memecahkan masalah, membuat rencana, dan memori jangka pendek.

b. Reptelian brain atau otak reptil atau disebut juga batang otak yang mengatur fungsi dasar seperti pernapasan, denyut jantung, suhu tubuh, sumber insting dasar manusia untuk melakukan pertahanan diri, bereaksi, mengulang, dan ritualis.

c. Lymbic system atau otak tengah yang berfungsi mengatur emosi, mengendalikan hormon dan sistem kekebalan tubuh, serta memori jangka panjang.

Untuk memberi gambaran yang lebih jelas tentang otak, disajikan gambar berikut ini.

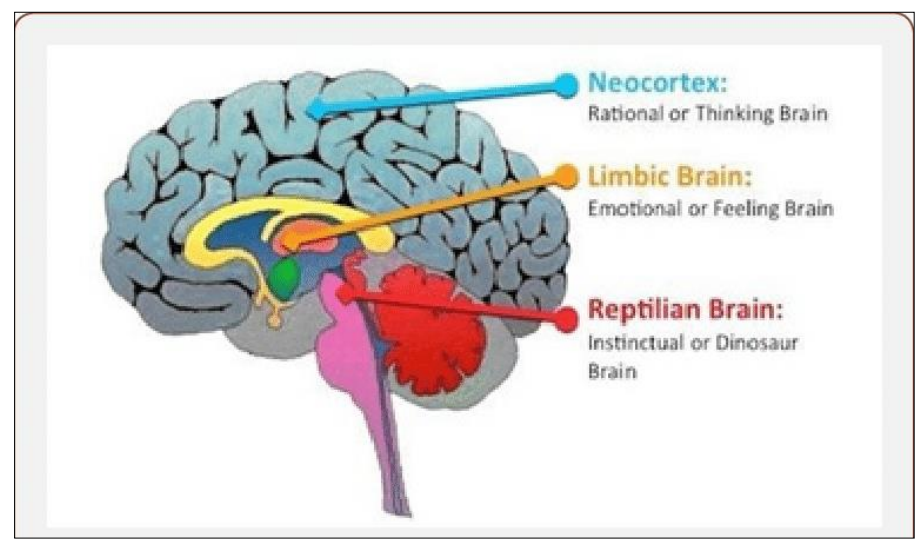

Gambar 1. Bagian-bagian Otak (Sumber: Luisetto, dkk., 2018). 
Konsep The Triune Brain Theory mendapat tanggapan positif dalam dunia pendidikan, terutama dalam kaitannya untuk mengembangkan model pembelajaran berbasis otak yang mampu memberdayakan seluruh potensi diri siswa. Pembelajaran berbasis otak ini kemudian dikenal sebagai model pembelajaran Brain Based Learning atau ada juga yang menyebutnya dengan istilah neorodidactics based learning dan neuropedagogy based learning. Ketiga istilah tersebut memiliki konsep dasar yang sama, yakni berhubungan dengan ilmu saraf sebagai ilmu yang membahas tentang struktur internal dan fungsi otak berdasarkan bidang neurologis yang dihubungkan dengan disiplin ilmu lain sehingga tercipta pendekatan multidisiplin dalam pelaksanaan pendidikan (Trnikovádan \& Petlák, 2012).

Pada dasarnya, setiap pembelajaran pasti menggunakan otak, tetapi konteks dalam model pembelajaran $B B L$ menekankan pembelajaran yang menyelaraskan cara kerja otak selama proses belajar berlangsung. Nur (2016) mendefinisikan model pembelajaran $B B L$ sebagai model pembelajaran yang melibatkan fungsi otak kiri dan otak kanan, agar siswa mampu berpikir kreatif untuk menggunakan dan memaksimalkan sistem kerja otak masing-masing, sehingga pembelajaran dapat berjalan secara optimal.

Dalam pelaksanaan penerapan model pembelajaran berbasis otak, terdapat enam hal yang perlu diperhatikan, yaitu (1) otak sebagai sistem belajar alami, (2) sistem belajar emosional, (3) sistem belajar sosial, (4) sistem belajar kognitif, (5) sistem belajar secara fisik, dan (6) sistem belajar secara reflektif (Given, 2002; Yufiarto \& Rihatno, 2017). Seluruh sistem belajar tersebut hendaknya diintegrasikan dalam pelaksanaan pembelajaran di kelas. Oleh karena itu, teori McClean (1970) tentang otak juga dikenal dengan Whole Brain karena melibatkan keseluruhan sistem otak selama proses belajar.

Berdasarkan pemaparan diatas, dapat disimpulkan bahwa model pembelajaran $B B L$ merupakan model pembelajaran yang memaksimalkan seluruh fungsi otak siswa selama proses pembelajaran berlangsung. Hal ini bertujuan agar antara otak kiri dan otak kanan memiliki sistem kerja yang seimbang. Selain itu, keberhasilan dari penerapan model pembelajaran $B B L$ tidak hanya dipengaruhi oleh cara kerja otak yang maksimal, tetapi juga membutuhkan bantuan dari aspekaspek lain seperti, aspek emosional, sosial, dan fisik siswa.

\section{Prinsip Dasar Model Pembelajaran BBL}

Pada umumnya, manusia tidak pernah menyadari kerumitan proses pengolahan bahasa dalam otak (Yusuf, 2017). Oleh sebab itu, guru sebagai salah satu penentu keberhasilan belajar siswa harus mampu memahami proses bahasa dalam otak manusia. Para guru bahasa asing atau dalam pembahasan ini adalah bahasa Jerman, diharapkan mampu melakukan pembaruan dan pematangan konsep pembelajaran melalui penerapan prinsip-pinsip pembelajaran berbasis otak. Penerapan model pembelajaran $B B L$ memiliki 12 prinsip yang berasal dari satu pemahaman tentang sistem kerja otak siswa (Schachl, 2006; Trnikovádan \& Petlák, 2012). Prinsip-prinsip tersebut adalah sebagai berikut.

\section{Prinsip 1: Overview before details (Umum ke khusus)}

Sebelum fokus menjelaskan materi utama, guru sebaiknya memberikan gambaran umum terkait materi yang akan dijelaskan. Hal ini dapat membantu 
otak siswa menemukan file memori yang sudah ada, kemudian menciptakan file baru di dalamnya (Schachl, 2006; Trnikovádan \& Petlák, 2012). Berdasarkan penjelasan tersebut, diberikannya gambaran umum terkait topik pembelajaran dapat memudahkan siswa untuk menggalih lagi ingatannya terkait materi yang pernah dijelaskan sebelumnya dan memiliki relefansi dengan materi yang akan diajarkan. Dengan demikian, siswa dapat mempersiapkan otak untuk menerima penjelasan lebih rinci terkait materi yang akan dipelajari pada hari itu.

\section{Prinsip 2: Clear teaching and learning aims (Tujuan pembelajaran dan} pembelajaran jelas)

Tujuan pembelajaran merupakan pernyataan-pernyataan tentang pengetahuan dan kemampuan yang diharapkan dapat dicapai oleh siswa setelah pelaksanaan pembelajaran berlangsung (Asrori, 2013; Cranton, 1989). Otak manusia lebih menyukai pertanyaan tentang "mengapa mempelajari sesuatu?" daripada "bagaimana mempelajari sesuatu?" (Schachl, 2006; Trnikovádan \& Petlák, 2012). Berdasarkan penjelesan ini, dapat disimpulkan bahwa siswa akan lebih tertarik mempelajari sesuatu apabila mereka telah mengetahuai tujuan dan alasan yang jelas mengapa mereka harus mempelajari materi tersebut. Oleh karena itu, dengan menginformasikan tujuan pembelajaran di awal pertemuan diharapkan dapat menarik perhatian siswa agar lebih fokus pada pembelajaran.

\section{Prinsip 3: Arouse interest (Membangkitkan minat)}

Minat yang kuat menjadi titik permulaan terbaik untuk menerima hal-hal baru dan menjadikan siswa lebih mudah untuk memasukkan materi pembelajaran ke dalam memori/ingatan (Schachl, 2006; Trnikovádan \& Petlák, 2012). Ada beberapa cara yang dapat dilakukan guru untuk meningkatkan minat siswa diantaranya yaitu, dengan menghubungkan materi pembelajaran dengan pengetahuan yang telah dimiliki siswa sebelumnya atau mengaitkannya dengan pengalaman siswa secara langsung, lalu mengemasnya dengan cara yang menarik, kreatif, komunikatif, dan interaktif. Berdasarkan penjelasan ini, dapat disimpulkan bahwa pengalaman langsung memiliki peran penting dalam proses pembelajaran. Siswa akan lebih paham terhadap suatu materi apabila mereka praktik langsung, atau guru dapat mengaitkan materi pembelajaran dengan hal-hal yang dekat dengan kehidupan siswa karena itu akan membuat pembelajaran menjadi lebih bermakna.

\section{Prinsip 4: Revision and repetition (Perbaikan dan pengulangan)}

Pepatah Romawi kuno mengatakan bahwa tidak ada pembelajaran yang dilakukan tanpa revisi (no studies without revision). Kebenaran dari pepatah kuno ini dibuktikan oleh ilmu saraf modern, yakni dengan melakukan aktivasi berulang pada sirkuit saraf dapat menciptakan kestabilan sistem otak (Schachl, 2006; Trnikovádan \& Petlák, 2012). Revisi dan pengulangan materi ini dapat dilakukan guru melalui pemberian Pekerjaan Rumah (PR) pada siswa. Melalui pengerjaan PR, siswa akan mengulang dan memperdalam kembali materi yang telah dipelajari di sekolah. Dengan demikian, kualitas ingatan siswa terkait suatu materi akan meningkat karena sering diadakannya revisi atau pemberian PR.

Prinsip 5: Multi-sensory approach (Pendekatan multisensorik)

Materi pembelajaran seharusnya tidak hanya masuk ke otak melalui mata dan telinga, tetapi juga melalui rangsangan sentuhan atau sense of touch (Schachl, 
2006; Trnikovádan \& Petlák, 2012). Artinya, pembelajaran yang baik adalah pembelajaran yang memposisikan siswa sebagai subjek dalam proses pembelajaran. Dengan kata lain, siswa harus lebih mendominasi untuk menggali dan mengembangkan pemahaman secara mandiri. Selain itu, siswa yang telah memiliki pemahaman dengan baik dapat menjelaskan kembali materi pada siswa lainnya (Schachl, 2006; Trnikovádan \& Petlák, 2012). Jadi, siswa dapat saling bertukar informasi dengan teman lainnya dengan harapan mereka mampu mencapai pemahaman yang setara atau sama.

\section{Prinsip 6: Affective factors (Faktor afektif)}

Stres dan kecemasan dapat menghalangi masuknya informasi ke dalam ingatan (Schachl, 2006; Trnikovádan \& Petlák, 2012). Menurut Ardiyani \& Yulianto (2017), menciptakan lingkungan pembelajaran yang menyenangkan dapat memunculkan emosi positif pada diri siswa. Selain itu, dalam mempelajari bahasa asing juga dibutuhkan suatu perasaan aman dan nyaman (Fachrurrozi \& Mahyudin, 2016). Dalam hal ini, aspek emosional atau perasaan memiliki peran penting terhadap keberhasilan suatu pembelajaran. Oleh karena itu, guru dapat menggunakan berbagai macam media dan metode agar dapat menciptakan situasi pembelajaran yang menyenangkan sehingga dapat memunculkan emosi postif pada diri siswa.

\section{Prinsip 7: Feedback (Umpan balik)}

Penelitian terkait cara kerja otak mengungkap bahwa pemberian umpan balik pada awal penyampaian materi merupakan hal yang sangat penting (Schachl, 2006; Trnikovádan \& Petlák, 2012). Selama informasi masih disimpan di sirkuit saraf (neural circuits), akan lebih mudah dilakukan perbaikan apabila terjadi kesalahan dalam penyampaian materi oleh guru (Schachl, 2006; Trnikovádan \& Petlák, 2012). Ketika memberikan umpan balik, guru sebaiknya tidak lupa untuk memuji, menguatkan dengan memberikan penjelasan yang lebih mendalam, dan mengonfirmasi apabila terdapat penjelasan yang kurang tepat (Schachl, 2006; Trnikovádan \& Petlák, 2012). Berdasarkan penjelasan ini, dapat disimpulkan bahwa umpan balik memiliki banyak manfaat dalam pelaksanaan pembelajaran. Seperti halnya umpan balik yang diberikan di awal pembelajaran dapat meminimalisasi kesalahan penyampaian informasi pada siswa. Selain itu, pemberian umpan balik yang berupa reward seperti pujian atau hadiah-hadiah kecil setelah siswa mengerjakan tugas atau menjawab kuis, dapat menambah motivasi siswa agar lebih semangat dalam belajar.

\section{Prinsip 8: Take breaks (Masa istirahat)}

Proses kimia yang belangsung untuk mengelolah seluruh informasi dalam otak memerlukan waktu dan tidak boleh diganggu oleh masuknya informasi tambahan (Jansen, 2011). Kegiatan yang dapat dilakukan selama masa istirahat ini adalah periode waktu tidur, bermain, mendengarkan musik, dan olahraga. Dari beberapa kegiatan tersebut, siswa lebih disarankan untuk melakukan kegiatan yang melibatkan latihan fisik dan tidak ada hubungannya dengan materi pembelajaran agar tidak menimbulkan kebingungan pada otak (Schachl, 2006; Trnikovádan \& Petlák, 2012). Berdasarkan penjelasan ini, masa istirahat sangat penting bagi siswa agar mereka tidak mengalami kejenuhan dalam belajar. Setelah istirahat, diharapkan dapat menumbuhkan semangat baru dalam 
diri siswa sehingga mereka dapat melanjutkan pembelajaran dengan baik hingga waktu pembelajaran berakhir.

\section{Prinsip 9: Sequencing in teaching and learning (Pengajaran dan pembelajaran terstruktur)}

Urutan langkah-langkah dalam pembelajaran memungkinkan untuk membangun hubungan yang efektif antara informasi baru dengan informasi sebelumnya yang masih memiliki keterkaitan (Schachl, 2006; Trnikovádan \& Petlák, 2012). Langkah-langkah pembelajaran yang tidak beraturan dapat menimbulkan gangguan dan tumpang tindih dalam proses pemerolehan informasi pada otak. Berdasarkan prinsip ini, guru sebaiknya menyusun rancangan pembelajaran secara terstruktur dan memiliki urutan yang tepat. Dengan terciptanya rancangan pembelajaran yang terstruktur, akan memudahkan siswa untuk menerima informasi baru dan mengaitkannya dengan informasi lama yang relevan sehingga pelaksanaan pengajaran dan pembelajaran akan terasa lebih bermakna bagi siswa.

\section{Prinsip 10: The importance of associative networks (Pengaruh penting jaringan asosiatif)}

Sejumlah eksperimen dalam psikologi kognitif menunjukkan bahwa memori manusia berfungsi sebagai jaringan (Schachl, 2006; Trnikovádan \& Petlák, 2012). Salah satunya adalah jaringan asosiatif. Jaringan asosiatif ini dapat dibangun melalui metode pembelajaran yang bervariasi, seperti pembelajaran berbasis konteks, pembelajaran multi-indra (multy-sensory learning), dan pembelajaran lintas-kurikuler (cross-curricular learning) (Schachl, 2006; Trnikovádan \& Petlák, 2012). Berdasarkan prinsip ini, dalam penerapan model pembalajaran $B B L$ guru dapat menggunakan berbagai metode pembelajaran. Dalam pemilihan metode pembelajaran, sebaiknya guru memilih metode yang variatif dan inovatif agar tidak monoton. Selain itu, metode pembelajaran yang dipilih diharapkan mampu membangkitkan semangat siswa sehingga dapat berpartisipasi secara aktif selama proses pembelajaran berlangsung.

\section{Prinsip 11: Specific aptitudes (Kemampuan khusus)}

Ini adalah prinsip penting dalam pelakasanan model pembelajaran $B B L$. Pada prinsip ini, guru memiliki tugas untuk mencari tahu kekuatan dan minat siswa secara spesifik (Schachl, 2006; Trnikovádan \& Petlák, 2012). Hal tersebut dilakukan dengan tujuan untuk meningkatkan dan mengasah kemampuan siswa dengan lebih baik. Selain itu, prinsip ini juga menunjukkan bahwa ketidakmampuan belajar dapat diatasi secara efektif melalui pelaksanaan remedial dengan menyesuaikan kemampuan masing-masing siswa (Schachl, 2006; Trnikovádan \& Petlák, 2012). Pada prinsip ini, menekankan bahwa setiap siswa pasti memiliki kemampuan dan minat yang berbeda-beda. Oleh karena itu, guru bertugas untuk mecari tahu hal tersebut agar dapat merancang suatu rencana pembelajaran yang tepat dan sesuai.

\section{Prinsip 12: Learning by imitation (Belajar dengan meniru)}

Imitasi itu perlu dan penting, terutama dalam pelaksanaan pembelajaran bahasa (Schachl, 2006; Trnikovádan \& Petlák, 2012). Oleh karena itu, guru harus sering memberikan contoh secara langsung kepada siswa. Sebagai contoh, dalam pembelajaran bahasa asing guru selalu melafalkan kosa kata dengan tepat dan 
mengarahkan siswa untuk mencontoh cara pelafalan tersebut. Hal ini harus dilakukan secara terus-menerus sampai siswa dapat menirukan dengan benar dan tepat. Setelah seluruh siswa mampu melafalkan suatu kosa kata dengan tepat, guru dapat menugaskan siswa untuk praktik berdialog bersama teman sebangku. Dengan demikian, kemampuan Sprechen (berbicara) siswa akan meningkat dengan baik.

Keduabelas prinsip di atas harus diperhatikan oleh guru dalam penerapan model pembelajaran $B B L$, agar guru dapat merancang pengalaman belajar yang menyenangkan, bermakna, dan memiliki kualitas tinggi bagi siswa. Selain itu, penerapan prinsip-prinsip di atas juga memberikan dampak positif bagi siswa. Beberapa dampak positif tersebut adalah siswa akan lebih termotivasi mengikuti pembelajaran, memiliki pemahaman konsep mendalam, dan mengembangkan keterampilan berpikir dengan baik (Nikmah, 2015).

\section{Kelebihan dan Kekurangan Model Pembelajaran $B B L$}

Salem (2017) menyebutkan tiga kelebihan model pembelajaran, yaitu:

a. $B B L$ memberi pengalaman belajar yang bermakna bagi siswa. Seluruh sistem otak bekerja secara kolaboratif dalam penerapan model pembelajaran ini sehingga memberi pengalaman belajar yang bermakna dan tidak mudah dilupakan oleh siswa (Caine \& Caine, 2006; Salem, 2017).

b. BBL membantu dalam menyimpan kosa kata baru. Penerapan model pembelajaran ini membantu siswa berlatih menyimpan informasi dalam otak secara permanen (Salem, 2017). Oleh karena itu, pembelajaran bahasa Jerman melalui model pembelajaran $B B L$ tidak berfokus pada peningkatan prestasi akademik dalam waktu singkat, melainkan meningkatkan kemampuan menjaga informasi dan pengetahuan yang telah dipelajari dalam jangka waktu yang lama.

c. $B B L$ meningkatkan motivasi belajar siswa. Penerapan model pembelajaran ini merupakan cara alami, memotivasi, dan positif untuk memaksimalkan pembelajaran karena mengikuti cara kerja otak secara alamiah (Caine \& Caine, 2006; Jansen, 2008; Salem, 2017).

Selain kelebihan yang telah disebutkan di atas, model pembelajaran $B B L$ juga memiliki kekurangan. Menurut Ibrahim (2016), kekurangan tersebut adalah sebagai berikut:

a. Diperlukan waktu yang cukup lama untuk memahami cara kerja otak siswa dalam memahami suatu permasalahan.

b. Diperlukan fasilitas yang memadai untuk mendukung praktik pembelajaran.

c. Diperlukan biaya yang lumayan banyak untuk menciptkan lingkungan pembelajaran yang nyaman dan baik untuk perkembangan otak siswa.

\section{Tahap-tahap Model Pembelajaran BBL Menurut Eric Jansen}

Jansen (2011) merancang tujuh tahap utama dalam penerapan model pembelajaran $B B L$. Ketujuh tahap tersebut adalah sebagai berikut:

\section{a. Pre-exposure (Tahap pra-pemaparan)}

Tujuan dari tahap ini adalah membantu otak dalam mengembangkan peta konseptual yang lebih baik sehingga otak siswa siap untuk menerima pengetahuan 
baru (Jansen, 2011). Menurut Handayani \& Corebima (2017), pada tahap ini guru juga dapat mendorong siswa agar lebih memperhatikan nutrisi otak dengan menyarankan siswa untuk mengonsumsi air minum yang cukup. Jadi, pada tahap ini berfokus untuk mengondisikan otak siswa agar lebih siap dalam menerima materi pembelajaran baru.

\section{b. Preparation (Tahap persiapan)}

Tujuan tahap ini adalah menciptakan rasa ingin tahu siswa terhadap materi yang akan diajarkan (Jansen, 2011). Pada tahap ini, guru dapat memberi stimulus dengan menciptakan pengalaman nyata yang relevan dengan topik pembelajaran. Selanjutnya, guru dapat mendorong siswa untuk berpikir tentang hubungan antara masalah atau fakta pada materi yang akan dipelajari dengan materi pembelajaran sebelumnya (Handayani \& Corebima, 2017). Sebagaimana yang telah dijelaskan di atas, bahwa siswa akan lebih mudah memahami materi apabila dikaitkan dengan pengalaman nayata atau hal-hal yang dekat dengan kehidupan siswa secara langsung.

\section{c. Initiation and Acquisition (Tahap inisisasi dan akuisisi)}

Pada tahap ini, guru dapat memberikan sedikit penjelasan kepada siswa dan membimbingnya untuk mencari informasi lebih dalam mengenai materi pembelajaran (Jansen, 2011). Dalam pelaksanaannya, guru dapat memberi kebebasan kepada siswa untuk mencari informasi di manapun, baik di dalam atau di luar kelas (Handayani \& Corebima, 2017). Dengan demikian, siswa dapat mengeksplorasi kemampuannya dalam menggalih suatu informasi.

\section{d. Elaboration (Tahap elaborasi)}

Tahap ini merupakan tahap pemrosesan. Siswa diberi kebebasan untuk mencari, menyaring, menganalisis, dan memperdalam materi pembelajaran (Jansen, 2011). Menurut Handayani \& Corebima (2017), pada tahap ini guru dapat mengarahkan siswa untuk membentuk kelompok dan melakukan disukusi bersama. Sebagaiman yang telah dijelaskan di atas, bahwa model pembelajaran $B B L$ memiliki konsep desain pembelajaran yang menyelaraskan sistem kerja otak secara alamiah untuk belajar sehingga siswa dapat belajar tanpa ada unsur keterpaksaan. Oleh karena itu, pada tahap ini guru memberikan kebebasan agar siswa dapat memperdalam pemahaman terhadap suatu materi dengan menggunakan caranya masing-masing.

\section{e. Incubation and Insert Memory (Tahap inkubasi dan internalisasi)}

Tahap ini menekankan pentingya waktu istirahat dan waktu untuk mengulang kembali (Jansen, 2011). Otak yang digunakan untuk belajar dapat bekerja paling efektif, apabila dilakukan dari waktu ke waktu, bukan langsung pada satu waktu. Menurut Jansen (2011), otak manusia dapat digunakan fokus dalam siklus waktu 90-100 menit. Oleh karena itu, agar pembelajaran berlangsung optimal dan menyenangkan, sebaiknya guru memberikan jeda waktu sekitar 10 menit agar siswa dapat beristirahat dan rileks. Sebagaiman yang telah dijelaskan di atas, bahwa masa istirahat memiliki peran penting dalam pembelajaran. Pada tahap ini, guru dapat memutarkan musik-musik kelasik dan mengarahkan siswa untuk meregangkan otot selama 5 menit sehingga mereka rileks kembali. Setelah itu, sisa waktu 5 menit dapat digunakan siswa untuk mencatat materi yang telah dijelaskan guru di papan tulis. 


\section{f. Verification and Checking Conviction (Tahap verifikasi dan konfirmasi)}

Pada tahap ini, guru mengecek apakah siswa telah memahami materi yang diajarkan (Handayani \& Corebima, 2017). Selain guru, siswa juga perlu mengomfirmasi diri sendiri, apakah mereka telah memahami materi dengan baik (Jansen, 2011). Apabila terdapat materi yang belum dipahami siswa, maka guru dapat menjelaskan lagi materi tersebut hingga mereka paham. Selain itu, guru juga dapat meminta tolong kepada siswa yang telah paham agar menjelasakan kembali materi pembelajaran pada siswa lain yang belum paham.

\section{g. Celebration and Integration (Tahap selebrasi dan integrasi)}

Pada tahap ini, sangat penting bagi guru untuk melibatkan emosi (Jansen, 2011). Menurut Jansen (2011), pembelajaran akan terasa sangat berkesan bagi siswa, jika apa yang telah diperjuangkan mendapat suatu penghargaan. Selain penghargaan, perayaan kecil juga diperlukan agar pembelajaran ditutup dengan hal yang menyenangkan. Dengan demikian, emosi postif dapat muncul dalam diri siswa sehingga pembelajaran menjadi lebih bermakna dan berkesan. Ketujuh tahap di atas hendaknya diterapkan dengan baik oleh guru sehingga penerapan model pembelajaran $B B L$ berjalan dengan baik dan efektif.

\section{Implementasi Model Pembelajaran $B B L$ dalam Pembelajaran Bahasa Jerman}

Berdasarakan paparan di atas, berikut ini disajikan contoh implementasi model pembelajaran $B B L$ dalam pembelajaran bahasa Jerman sebagai bahasa asing di SMA untuk kelas X, semester 2, tema Schulsachen (alat sekolah) dengan struktur materi pembelajaran bestimmte Artikel.

\section{a. Pre-exposure (Tahap pra-pemaparan)}

Untuk menyiapkan otak siswa agar mampu menerima pengetahuan baru, guru dapat memulai pembelajaran dengan melakukan pemanasan (warming up). Sebagai contoh, pemanasan dapat dilakukan dengan mengajak siswa menyanyikan lagu-lagu bahasa Jerman dan melakukan gerakan-gerakan untuk meregangkan otot, seperti memutar tubuh ke kanan dan ke kiri, ke depan dan ke belakang, dan seterusnya. Setelah itu, untuk mengembangkan peta konseptual yang dimiliki siswa, guru dapat mengajukan beberapa pertanyaan dalam bahasa Jerman terkait materi sebelumnya, seperti "Was habt ihr schon gelernt?" (Apa yang telah kalian pelajari sebelumnya?). Tahap ini, diakhiri dengan guru menyampaikan tujuan pembelajaran kepada siswa. Sebagai contoh, sebelum guru menjelaskan tema Schulsachen (alat sekolah), sebaiknya guru memberikan penjelasan tentang kegunaan/tujuan mempelajari materi tersebut, yaitu agar siswa dapat mendeskripsikan, menceritakan, dan menanyakan tentang alat- alat sekolah-dalam bahasa Jerman.

\section{b. Preparation (Tahap persiapan)}

Untuk memberi stimulus kepada siswa, guru dapat mengaitkan materi pembelajaran dengan realita yang ada dalam kehidupan sehari-hari (Handayani \& Corebima, 2017). Sebagai contoh, guru dapat menunjuk beberapa alat sekolah yang dimiliki siswa, kemudian mengajukan pertanyaan "Wie heißt das auf Deutsch?" (Apa nama benda ini dalam bahasa Jerman?) dengan berulang kali. Selain itu, pada tahap ini guru sebaiknya menggunakan media yang menarik dan kreatif, seperti gambar, video, film, anime, atau boneka tangan. Sebagai contoh, 
guru dapat memutar video/anime tentang nama-nama alat sekolah dalam bahasa Jerman. Setelah itu, guru mengarahkan siswa untuk membuat asosiogram dengan menulis nama-nama alat sekolah sesuai informasi dalam video, di papan tulis. Selanjutnya, guru akan mengoreksi dan menambahkan bestimmte Artikel (der, die, das) di depan nama-nama benda yang telah ditulis siswa. Untuk menciptakan rasa ingin tahu siswa lebih dalam, guru dapat bertanya "Was bedeutet das?" (Apa maksudnya?) dengan menunjuk tulisan Artikel tersebut.

\section{c. Initiation and Acquisition (Tahap inisisasi dan akuisisi)}

Sebagaimana yang telah dijelaskan sebelumnya, pada tahap ini guru dapat menerangkan materi secara singkat, lalu membimbing siswa agar mencari informasi lebih dalam secara mandiri (Jansen, 2011). Sebagai contoh, guru akan memberi sedikit penjelasan tentang materi bestimmte Artikel, kemudian siswa ditugaskan untuk membaca dan menganalisis dialog sederhana tentang alat sekolah. Setelah itu, siswa diarahkan untuk menggarisbawahi Artikel (der, die, das) dalam dialog. Untuk menggali informasi lebih dalam terkait materi ini, guru dapat membimbing siswa mencari perbedaan penggunaan der, die, das berdasarkan kalimat dalam dialog yang disajikan. Siswa diberi kebebasan untuk menggali informasi dari buku, modul, kamus, maupun internet.

\section{d. Elaboration (Tahap elaborasi)}

Pada dasarnya, otak manusia menyukai kegiatan yang dilakukan secara berkelompok (Yusuf, 2017). Oleh karena itu, pada tahap ini siswa diberi kebebasan membentuk kelompok dengan tujuan untuk menyaring, menganalisis, dan memperdalam materi pembelajaran dengan cara berdisukusi bersama. Sebagai contoh, guru dapat memberi tugas kepada siswa untuk melengkapi tabel rumpang dengan nama-nama alat sekolah sesuai jenis Artikel yang tepat. Dengan demikian, siswa diharapkan dapat mencari jawaban melalui diskusi bersama kelompok masing-masing.

\section{e. Incubation and Insert Memory (Tahap inkubasi dan internalisasi)}

Sebagaimana yang telah dijelaskan di atas, tahap ini menekankan pentingnya memberikan siswa jeda waktu istirahat dan waktu mengulang kembali (Jansen, 2011). Sebagai contoh, guru dapat memutar musik-musik klasik dan menyarankan siswa melakukan gerakan untuk meregangkan otot agar kembali rileks. Selain itu, siswa dapat menggunakan waktu tersebut untuk mengulang kembali materi pembelajaran dengan cara mencatat materi yang telah dijelaskan guru di papan tulis.

\section{f. Verification and Checking Conviction (Tahap verifikasi dan konfirmasi)}

Pada tahap ini, dilakukan pengecekan terkait pemahaman materi, baik oleh guru maupun oleh siswa secara mandiri (Handayani \& Corebima, 2017). Sebagai contoh, guru dapat menunjukkan beberapa gambar dan mengarahkan siswa untuk menebak nama-nama alat sekolah tersebut dalam bahasa Jerman beserta Artikel yang tepat. Kegiatan ini dapat dilakukan berulang-ulang, sampai sebagian besar siswa di kelas mampu menjawabnya dengan benar. Setelah itu, guru juga dapat menanyakan kembali penjelasan terkait perbedaan Artikel (der, die, das). 


\section{g. Celebration and Integration (Tahap Selebrasi dan Integrasi)}

Agar pembelajaran ditutup dengan hal-hal yang menyenangkan, pada tahap ini guru dapat memberikan penghargaan kepada siswa atau melakukan perayaan kecil atas keberhasilan pembelajaran yang telah dicapai. Sebagai contoh, guru dapat memberikan hadiah atau reward kepada siswa yang aktif, baik sebagai individu maupun kelompok, dengan tujuan untuk memotivasi dan meningkatkan rasa percaya diri siswa. Selain itu, contoh perayaan kecil yang dapat dilakukan siswa sebagai bentuk pengekspresian kegembiaraan atas keberhasilan pembelajaran yang dilalui adalah dengan menyerukan yell-yell secara serentak.

\section{KESIMPULAN}

Seiring dengan revolusi dalam dunia pendidikan, pembelajaran bahasa Jerman dengan menggunakan model pembelajaran tradisional sudah tidak relevan lagi. Pelaksanaan pembelajaran di sekolah membutuhkan suatu model pembelajaran inovatif yang dapat menciptkan situasi yang nyaman, menyenangkan, dan bermakna bagi siswa. Untuk mewujudkan situasi tersebut, guru perlu memahami cara kerja otak siswa sebagai pusat sistem kecerdasan manusia. Salah satu model pembelajaran yang dapat mengakomodasi hal tersebut adalah model pembelajaran berbasis otak atau $B B L$.

Model pembelajaran $B B L$ menganut konsep pembelajaran yang menyelaraskan cara kerja otak siswa selama proses pembelajaran berlangsung. Penerapan model pembelajaran $B B L$ memiliki 12 prinsip dasar, yaitu: overview before details, clear teaching and learning aims, arouse interest, revision and repetition, multy-sensory approach, affective factors, feedback, take breaks, sequencing in teaching and learning, the importance of associative networks, spesific aptitudes, dan learning by imitation. Sementara itu, penerapan model pembelajaran $B B L$ terdiri atas 7 tahap, yakni (1) tahap pra-pemaparan, (2) tahap persiapan, (3) tahap inisiasi dan akuisisi, (4) tahap elaborasi, (5) tahap inkubasi dan memasukkan memori, (6) tahap verifikasi dan pengecekan keyakinan, serta (7) tahap perayaan dan integrasi.

Pembelajaran bahasa Jerman dengan menggunakan model pembelajaran $B B L$ memberi dampak positif bagi siswa. Salah satunya adalah membantu siswa untuk mengingat kosakata baru dalam jangka waktu yang lama. Selain itu, penerapan model pembelajaran ini dapat mengasah seluruh potensi yang dimiliki siswa, sehingga pembelajaran berlangsung secara optimal. Potensi-potensi siswa yang dapat dikembangkan dalam hal ini antara lain, kemampuan menulis, membaca, menganalisis, mengendalikan emosi, berkomunikasi, berinteraksi dan bersosialisasi.

Oleh karena itu, model pembelajaran $B B L$ dapat digunakan sebagai solusi alternatif untuk meningkatkan kualitas pembelajaran bahasa Jerman di SMA. Melalui model pembelajaran ini, pembelajaran bahasa Jerman diharapkan mampu menghasilkan siswa dengan kualitas output yang sesuai dengan tujuan pembelajaran yang telah ditetapkan, yakni siswa mampu menggunakan bahasa Jerman dalam konteks komunikasi lisan dan atau tulis dengan baik dan tepat. 


\section{SARAN}

Berdasarkan kesimpulan di atas, hasil kajian artikel ini diharapkan dapat memberi sumbangan ilmu pengetahuan terkait pentingnya inovasi dalam mengembangkan model pembelajaran untuk meningkatkan hasil belajar siswa. Selain itu, penerapan model pembelajaran $B B L$ diharapkan dapat dijadikan sebagai alternatif dalam pemilihan model pembelajaran bagi guru, terutama untuk pembelajaran bahasa Jerman di tingkat SMA/MA. Bagi peneliti yang memiliki minat terkait pembahasan mengenai model pembelajaran, dapat menjadikan kajian artikel ini sebagai salah satu bahan acuan/referensi untuk melaksanakan penelitian selanjutnya, terutama terkait pengembangan model pembelajaran bahasa Jerman.

\section{DAFTAR RUJUKAN}

Ardiyani, D. K., \& Yulianto, B. 2017. Neurodidactic-Based Learning on German Course (Deutsch) B1 Level. Research on Humanities and Social Sciences, $\quad$ (Online), 7 (24): 40-47, (https://pdfs.semanticscholar.org/9243/adf136958fda3b2ad6b50a7cf8f68 8d10397.pdf), diakses tanggal 31 Mei 2020

Asrori, M. 2013. Pengertian, Tujuan dan Ruang Lingkup Strategi Pembelajaran. Madrasah: Jurnal Pendidikan dan Pembelajaran Dasar, (Online), 5 (2): 162-188, (http://ejournal.uinmalang.ac.id/index.php/madrasah/article/viewFile/3301/5117), diakses tanggal 23 Juni 2020.

Barkowski, H., \& Krumm, H. J. (Eds.). 2010. Fachlexikon Deutsch als Fremdund Zweitsprache (Vol. 8422). UTB.

EF EPI. 2019. EF EPI 2019. EF English Proficiency Index, (Online), (https://www.ef.com/_/ /media/centralefcom/epi/downloads/fullreports/v9/ef-epi-2019-english.pdf), diakses tanggal 17 Juli 2020.

Efendi, M. R. 2013. Brain Based Learning dalam Pembelajaran Bahasa Asing. Infodiknas.com, (Online), (http://www.infodiknas.com/brain-basedlearning-dalam-pembelajaran-bahasa-asing-2.html), diakses 31 Maret 2020.

Fachrurrozi, Aziz \& Erta Mahyudin. 2016. Pembelajaran Bahasa Asing Tradisonal \& Kotemporer. Jakarta: Rajawali Pers.

Haeniah, N. 2019. Logika Dalam Pembelajaran. Jurnalistrendi: Jurnal Linguistik, Sastra, dan Pendidikan, (Online) 4(1): 300-308 (http://ejournal.unwmataram.ac.id/trendi/article/download/170/122), diakses tanggal 18 Maret 2020.

Handayani, B. S., \& Corebima, A. D. 2017. Model Brain Based Learning (BBL) and Whole Brain Teaching (WBT) in Learning. International Journal of Science and Applied Science: Conference Series, (Online), 1 (2): 153161 , (https://pdfs.semanticscholar.org/39b9/840e8a3ff47c7ee29a420e12aa17b df0adf6.pdf), diakses tanggal 24 April 2020.

Ibrahim, D. 2016. Pengaruh Model Pembelajaran Brain Based Learning Terhadap Aktivitas Belajar Siswa. Atthulab: Islamic Religion Teaching and Learning Journal, (Online), 1(2): 159-173 
(http://journal.uinsgd.ac.id/index.php/atthulab/article/download/2525/250 2), diakses tanggal 22 April 2020.

Jansen, E. 2011. Pembelajaran Berbasis Otak Edisi Kedua. Terjemahan B. Molan. Jakarta: PT Indeks.

Khosiyono, B. H. C. 2018. Kebijakan Pendidikan Bahasa Asing di Indonesia dalam Perspektif Masyarakat Global. Jurnal Pembangunan Pendidikan: Fondasi dan Aplikasi, (Online), 6(1): 70-82, (https://journal.uny.ac.id/index.php/jppfa/article/download/20612/11738) , diakses tanggal 12 Maret 2020.

Luisetto, M., Naseer, A., Ghulam, R. M., Ahmed, Y. R., \& Farhan, A. K. (2018). Endogenous Archeological Sciences: Anatomy, Physiology, Neuroscience, Biochemistry, Immunology, Pharmacology, Oncology, Genetics as Instrument for A New Field of Investigation? Modern Global Aspects for A New Discipline. Open Access J Addict \& Psychology, (Online), $\quad 1 \quad$ (3): 1-18, (https://www.researchgate.net/profile/Mauro_Luisetto/publication/33574 9857_JPCR_Luisetto_M_Naseer_A_Ghulam_R_M_Ahmed_Yesvi_Farh an_A_K_et_al_Endogenous_Archeological_Sciences_pdf/data/5d7909c8 4585151ee4aee132/JPCR-Luisetto-M-Naseer-A-Ghulam-R-M-AhmedYesvi-Farhan-A-K-et-al-Endogenous-Archeological-Sciences.pdf), diakses tanggal 08 November 2020.

Niekra, U. 2016. Deutsch als Fremdssprasche-Fach pder Disziplin?. Studia methodologica, (Online), 42 (1): 43-51, (http://www.irbisnbuv.gov.ua/cgi-

bin/irbis_nbuv/cgiirbis_64.exe?C21COM=2\&I21DBN=UJRN\&P21DBN $=U J R N \& I M A G E \_F I L E \_D O W N L O A D=1 \&$ Image_file_name $=P D F / s t u d$ method_2016_42_7.pdf), diakses tanggal 13 Maret 2020.

Nikmah, A. 2015. Pembelajaran melalui Brain Based Learning dalam Pendidikan Anak Usia Dini. ThufuLA: Jurnal Inovasi Pendidikan Guru Raudhatul Athfal, (Online),

202-218,

(http://journal.iainkudus.ac.id/index.php/thufula/article/download/4260/2 762), diakses tanggal 04 Mei 2020.

Nur, I. R. D. 2016. Meningkatkan Kemampuan Berpikir Kreatif Matematis dan Kemandirian Belajar Siswa dengan Menggunakan Model Pembelajaran Brain Based Learning. JUDIKA (Jurnal Pendidikan Unsika), (Online), 4 (1):

202-218, (https://pdfs.semanticscholar.org/5a2e/13a451befc6dc6fc8ffdc977ac7720 980728.pdf), diakses tanggal 06 Mei 2020.

Salem, A. A. M. S. 2017. Engaging ESP Students with Brain-based Learning for Improved Listening Skills, Vocabulary Retention and Motivation. English Language Teaching,(Online), 10(12): 182-195, (https://files.eric.ed.gov/fulltext/EJ1160987.pdf), diakses tanggal 24 April 2020.

Septami, E. G. K. 2015. Upaya Peningkatan Keterampilan Berbicara Bahasa Jerman Peserta Didik kelas XI IPA 1 SMA Negeri 1 Sidayu Bantul melalui Kartu Domino.

Dari 
http://eprints.uny.ac.id/16415/1/Erlita\%20Galih\%20KS\%201020324403 9.pdf.

Suryaningrum, L. D. 2016. Karakteristik Pembelajaran Bahasa Jerman di SMA Nusantara. http://eprints.uny.ac.id/30508/1/Skripsi_Lina\%20Dessy\%20Suryaningru m_11203241019.pdf.

Triyono, S. 2012. Deutsch zum Spass: Model Pembelajaran Inovatif Bahasa Jerman. Jurnal Pendidikan Bahasa dan Sastra, (Online), 12(2), (https://ejournal.upi.edu/index.php/BS_JPBSP/article/view/3696/2628), diakses tanggal 19 Februari 2020.

Trníková, J., \& Petlák, E. 2012. Neuroscience as a Basis for Innovations in Education. Acta Educationis Generalis, (Online), 2(2): 43-51, (https://content.sciendo.com/downloadpdf/journals/atd/2/2/articlep43.pdf), diakses tanggal 19 Februari 2020.

Widyantara, I. G., Ganing, N. N., \& Zulaikha, S. 2015. Pembelajaran Berbasis Otak Berbantuan Media Visual Berpengaruh terhadap Keterampilan Menulis Deskripsi Bahasa Indonesia Siswa Kelas V SD Gugus 2 Mengwi Badung. Mimbar PGSD Undiksha, (Online), 2(1): 1-10, (https://ejournal.undiksha.ac.id/index.php/JJPGSD/article/download/453 5/3494), diakses tanggal 30 Januari 2020.

Wirajayadi, L. 2016. Apresiasi Teks Cerpen Di SMP melalui Model Pembelajaran Berbasis Penemuan. Jurnalistrendi: Jurnal Linguistik, Sastra, dan Pendidikan, (Online), 1 (1): (http://ejournal.unwmataram.ac.id/trendi/article/download/24/17), diakses tanggal 15 Mei 2020.

Yufiarto \& Rihatno, Taufik. 2017. Brain Based Teaching, (Onlien), (http://sipeg.unj.ac.id/repository/upload/buku/BRAIN_BASED_TEACHI NG_+_haki.pdf), diakses 28 Mei 2020.

Yulvinamaesari, Y. 2014. Implementasi Brain Based Learning dalam Pembelajaran Berbasis Pendidikan Karakter. Prosiding, (Online), 1(1): 99-106, (http://journal.uncp.ac.id/index.php/proceding/article/view/229/218) ,diakses tanggal 31 Mei 2020.

Yusuf, Y. P. 2017. Strategi Brain Based Learning dalam Pengajaran Bahasa Jepang di MAN Mojokerto. Paramasastra, (Online), 4(1): 98-118, (https://journal.unesa.ac.id/index.php/paramasastra/article/download/148 5/1000), diakses tanggal 31 Mei 2020. 